\title{
DOMESTIC LABOUR MIGRATION IN RUSSIA: INCIDENCE AND GEOGRAPHY OF MIGRATION
}

\author{
L.Karachurina, National Research University - Higher School of Economics
}

The possibility of active and effective usage of domestic labor reserves used to be offered for discussion following a reduction in and slower growth of working-age population in Russia ${ }^{1}$ and growth in external labor migration from CIS member countries to Russia throughout the entire 2000x. The need to accelerate domestic "permanent" migration from labor-force-redundant to labor-force-deficit regions, as well as more actively encourage domestic temporal labor migrants to move to certain areas/zones of economic growth were listed among such measures.

These discussions acquired a new context during the crisis of 2008-2009, and it wouldn't be superfluous to recall them in anticipation of economic hardships. Targeted support to individuals ready to move for job substitution from highly unemployed areas to other regions was announced among the four measures to combat unemployment during the crisis of 2009. Originally, 100,000 persons $^{2}$ were expected to receive migration support, but the figure was reduced to 15,900 persons at the stage of concluding contracts with regions. Eventually, actual support was rendered to 11,000 persons through spending $70 \%$ of the funds allocated to finance these measures ${ }^{3}$. Those Russia's nationals to whom such a support was offered, were reluctant to take it. Domestic mobility of unemployed persons and job seekers which was studied by the request of the Federal Labor and Employment Service ${ }^{4}$ in all Russia's regions in two 'waves', namely prior to (October 2008) and during the crisis (December 2009), showed that readiness to work in other region had almost nothing to do with unemployment and fear of job loss, and stood at $4.2 \%$ prior to the crisis and $4.4 \%$ during 'crisis survey'.

A survey of working and unemployed people's migration intentions which was conducted in 2006 by

\footnotetext{
1 We remind that the working-age population decreased in 2006 for the first time in the Soviet and Russian history, and has been decreasing in Russia since 2006. The working-age population decreased by 927,300 persons in 2011 and the first two months of 2010 alone (based on the data of the National Population Census 2010) // Demografichesky ezhegodnik Rossii - 2012. Rosstat, 2013. 2 Reaching the workplace // SmartMoney, May 18, 2009

3 Progress monitoring of regional programs which provide for extra measures aimed at easing tensions in the labor market (January thru December 2009) M.: Rostrud, 2010, p. 11). The state guaranteed as part of the program to cover transport costs, rentals ( $\mathrm{Rb}$ 550 daily for 3 months on average), and pay a travelling allowance. 4 State contract "Developing a model of organization of employment in other places for job seekers by state service bodies" headed by M. B. Denisenko).

5 Denisenko M., Karachurina L., Mkrtchan N. Whether or not Russia's unemployed ready to move for work? // Demoscope Weekly, No. 445-446) http://demoscope.ru/weekly/2010/0445/ index.php
}

the Center for Migration Studies in 10 largest cities in Russia, revealed that the effect of job satisfaction on migration mobility was much weaker than it was expected $^{6}$. The data of the survey showed that $4.4 \%$ of respondents had session work (save for pendulum migration and rotation based work) within the past two years or members of their families used to move to other places to find a job, including representatives of $1.7 \%$ of households who did that on a regular basis. Session work was the key and/or sole employment for at least $2 / 3$ of the respondents.

Permanent migration in the post-Soviet period was more intensively substituted with different forms of temporal labor migration, reaching the scale comparable with seasonal work at the turn of $19^{\text {th }}-20^{\text {th }}$ centuries. However, no sufficient information is available on temporal labor migration.

In 2010, Rosstat (Federal State Statistics Service) for the first time began to compile data on workplace as part of its regular Population Surveys in order to study employment issues, and included a small set of migration-related questions into them in 2012. The workplace question was also included into the 2010 census questionnaire. These data were published in $2013^{7}$.

According to the PSEI data on 2012, 2,3 million persons, accounting for $2.1 \%$ of the population at the age of $15-72$, or $3.2 \%$ of those who specified their workplace, worked outside their place of residence. The difference can be explained basically by the fact that $35.1 \%$ of the PSEI respondents were primarily very young and pension-aged people.

The presented data may be interpreted as a measure of the scale of temporal labor migration, but sub-

6 Karachurina L., Mkrtchan N. Migration activity of working and unemployed people (based on the data of a social survey conducted in 10 large Russia's cities // Demoscope Weekly. 2009. No. 401402) http://demoscope.ru/weekly/2009/0401/analit05.php

7 See the Official Results of the National Population Census 2010, Vol. 8 http://www.gks.ru/free_doc/new_site/perepis2010/ croc/perepis_itogi1612.htm 
ject to certain reservations: temporal labor migration may take place within regions. Remote towns and areas are often located $100-150 \mathrm{~km}$ as far as regional capitals in Russia, thus making impossible daily pendulum-like traveling to the workplace. Therefore, one should take into account that, according to the PSEI data, another 4,1 million Russia's nationals worked in other city (district ${ }^{1}$ ), and some of them were temporal labor migrants too.

However, having a job in other region doesn't always imply involvement in temporal labor migration, because it may be pendulum migration in certain cases. It is pendulum migration that employment in other region should be referred to for most of those living in the Moscow ${ }^{2}$ and Leningrad Regions and travelling daily to their workplace in metropolitan centers, as well as those living in Moscow and St. Petersburg and working in the respective regions. The headcount of such workers totaled 715,000 in 2012, thereby reducing substantially total number of temporal labor migrants according to the PSEI data. It is even more reasonable that 760,000 persons working in other region travelled on a daily basis. According to the trip frequency criterion, net of pendulum migration cases, the headcount of temporal labor migrants, according to PSEI data, totaled 1,6 million, or accounted for $2.2 \%$ of the total employed persons in 2012.

Unlike the census data ${ }^{3}$, PSEI materials are illustrative of the structural components of temporal labor migration. Males and females account for $75.7 \%$ and $24.3 \%$ of temporal labor migrants respectively, with males largely outnumbering females. Age-related distribution of temporal labor migrants is shifted towards older ages vs. 'permanent' migrants including many college-aged young people (Fig. 1). Distribution of migrants by marital status corresponds approximately to the national average $-51.7 \%$ labor migrants were married (55.5\% of total population, according to the 2010 census data).

Education level of temporal labor migrants corresponds in general to the distribution for the population in total, but they contain less persons with higher and secondary vocational education, and more ones with secondary vocational and general secondary education. Perhaps, such a distribution of domestic labor migrants by level of education can be explained by employment in the construction industry and indus-

1 Exclusive of urban districts.

2 Shitova Y.Y. Pendulum labor migration in the Moscow Region: methodological and applied analysis // Ekonomichesky Zhurnal HSE. 2006. No. 1, pp. 63-79)

3 See the Official Results of the National Population Census 2010, Vol. 8 http://www.gks.ru/free_doc/new_site/perepis2010/ croc/perepis_itogi1612.htm)

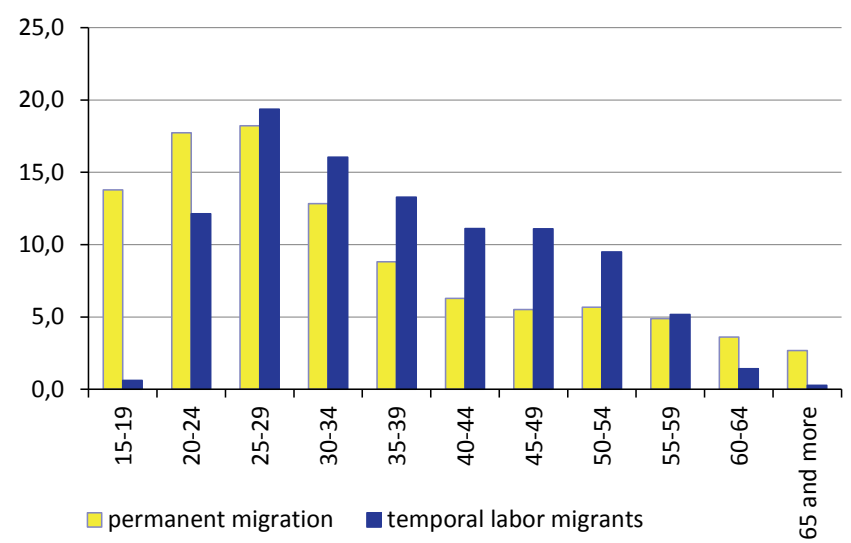

Source: Rosstat: running records; PSEI data.

Fig. 1. Distribution of domestic (permanent migration) and temporal labor migrants in Russia by age in 2012, as \% of total headcount of migrants at the age of 15-72

trial sector ${ }^{4}$. The following occupations are prevailing: motor vehicle drivers, security personnel, retail sales personnel, loaders and common labor personnel, construction workers and construction \& installation personnel, welding and oxygen-cutting operators, construction unskilled labor force, well-drill operators, bricklayers, and accouters. These are most widespread occupations which account for $40 \%$ of all domestic labor migrants in Russia.

Not counting citizens of Russia's largest (Moscow and St. Petersburg) agglomerations, the Central Federal District (Ivanovo, Tula, Tambov, Smolensk, Kursk, Bryansk Regions) and the Volga Region (the Chuvash Republic, the Republics of Mari El, Mordovia, Bashkortostan, and Penza Region) would be distinguished by a share of temporal labor migrants (working in other regions) in the total employed population, where persons working in other regions accounted for $5-10 \%$ in 2012. The Kurgan Region accounts for the biggest share of temporal migrants in the Urals, the Republic of Kalmykia in the Sothern Federal District, the Omsk Region in Siberia. Almost all of the above listed regions are economically depressed or falling far behind the neighboring regions.

According to PSEI data, Moscow Region (Moscow and Moscow Region) is most attracting for temporal labor migrants. Not counting mutual pendulum-like trips between these regions, the headcount of temporal labor migrants from other regions would be 851,000 persons, or $7.4 \%$ of the total employed. The Moscow Region is ranked \#1 in the number of labor migrants terms, followed far behinds by the KhantyMansi Autonomous Area with 97,000 labor migrants,

$4 \quad$ Labor market trends. Analytical materials). Rosstat's official website. http://www.gks.ru/bgd/regl/B11_04/IssWWW.exe/Stg/ d03/2-rin-trud.htm 
accounting for mere $10 \%$ of the total employed in this Federal District. The Yamalo-Nenets Autonomous District has 46,000 labor migrants (Russia's nationals), but this is $13 \%$ of the total employed. St. Petersburg and the Leningrad Region have 63,000 labor migrants, not counting trips between these regions, but they account for mere $1.6 \%$ of the employed. The Krasnodar Territory, the Sverdlovsk Region, the Republic of Tatarstan, Samara and Rostov Regions are significant centers of attraction for labor migrants which account for no more than $2 \%$ of the total employed persons.

PSEI data shows principal routs of labor migration within Russia. The Moscow Region attracts labor migrants primarily from the nearest regions such as Tula, Vladimir, Tver, Kaluga, Smolensk, Ivanovo Regions, as well as remote regions, namely Penza, Bryansk, Tambov, Rostov Regions, the Chuvash Republic, and the Republic of Mordovia. Workforce flow to the Moscow Region from the eastern areas of the country was insignificant.

The Republic of Bashkortostan which accounts for $40 \%$ of total labor migration to the Federal District is the key migration 'donor' for the Khanty-Mansi Autonomous Area. Omsk, Kurgan, Sverdlovsk Regions, the Republic of Tatarstan, the Chelyabinsk Region can be distinguished too. The Yamalo-Nenets Autonomous District looks attractive for labor migrants from the Republic of Bashkortostan (34\%), as well as Omsk, Kurgan, Kirov Regions, and the Republics of Tatarstan and Udmurtia. St. Petersburg and the Leningrad Region are more attractive basically for the population of the Northwestern Federal District: Pskov, Novgorod and Tver Regions.

PSEI data are supported by the development of materials of the National Population Census 2010 which show that the same 2,3 million Russia's nationals worked in other regions. The data of the National Population Census $2010^{1}$ show that $96.3 \%$ of the employed Russia's nationals at the age of $15-72$ who specified their workplace location worked in their region of residence; $85.5 \%$ worked in their place of residence. Therefore, not only is spatial labor mobility low in general, but also a share of those who didn't move even within their own region is big.

For example, the data of annual population surveys in France in $2007^{2}$ show that places of residence and work differed for almost $65 \%$ of the employed; $17 \%$ persons moved to other departments for work ${ }^{3}$. Even trans-regional labor movements are insignificant and

1 See the Official Results of the National Population Census 2010, Vol. 8 http://www.gks.ru/free_doc/new_site/perepis2010/ $\mathrm{croc} /$ perepis itogi1612.htm

2 Have been conducted since 2004 instead of one-state censuses common for Russians.

3 Denisenko M., Karachurina L., Mkrtchan N. Whether or not Russia's unemployed ready to move for work? // Demoscope Weekly, No. 445-446) http://demoscope.ru/weekly/2010/0445/tema01.php

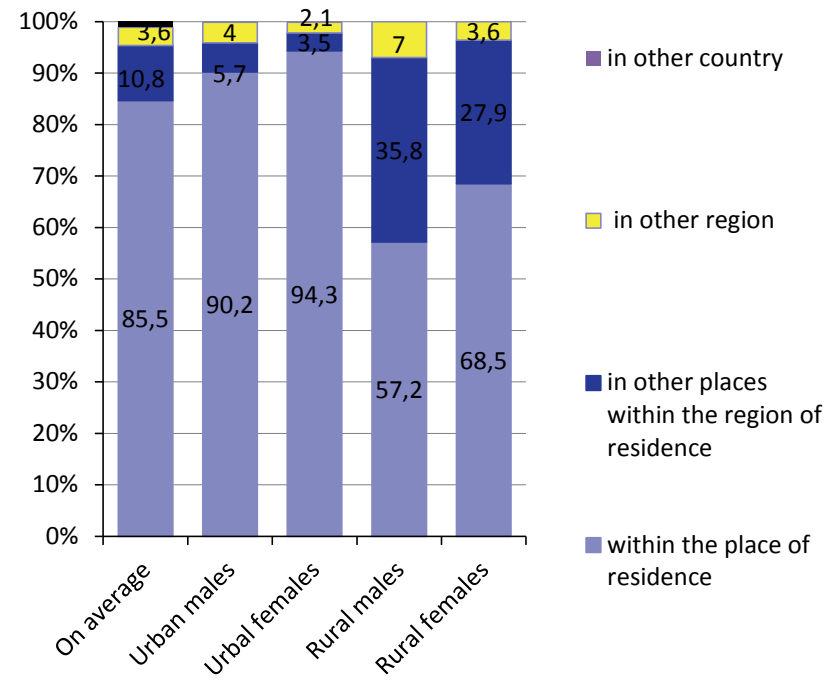

Source: based on the data of the National Population Census 2010.

Fig. 2. Workplace location of employed private household population at the age of 15-72 by category of population, \%, 2010 (excluding those who didn't specify their workplace location)

challenging in modern Russia, when only regional centers have more or less diverse labor market in relatively developed, developing, and depressed regions, and spatial linkage is weak.

Rural male population are most mobile in Russia: just a bit more than $50 \%$ of them work at the place of their residence, of which a share of workers employed in other regions is bigger too. Urban female population show the lowest labor mobility (Fig. 2).

Near-to-capital territories (the Moscow and Leningrad Regions account for one fourth of such territories $^{4}$ ) and such regions as the Republic of Adygeya or the Jewish Autonomous Region which have historical links with the 'parent' Krasnodar and Khabarovsk Territories show high parameters of employment outside the area of residence. More compact (thus spatially traversable) and adjacent-to-Moscow areas in the Central Federal District are distinguished by lower according to Russian standards - level of employment. $98-100 \%$ of the population are employed within their area or residence in 20 Russia's regions. However, the 'nature' of high level of employment outside the area of residence in the Moscow and Leningrad Regions differs from the Chuvash Republic. The former refers to the classic pendulum migration, whereas the latter to temporal labor migration from home to the workplace for several weeks or months.

Trans-regional labor mobility is minimal in the eastern regions of the country, where neither trans-

4 However, it is just over half of the Moscow Region population that work in their place of residence, whereas 'home' employment accounts for more than $90 \%$ in certain Siberian areas and Moscow. 


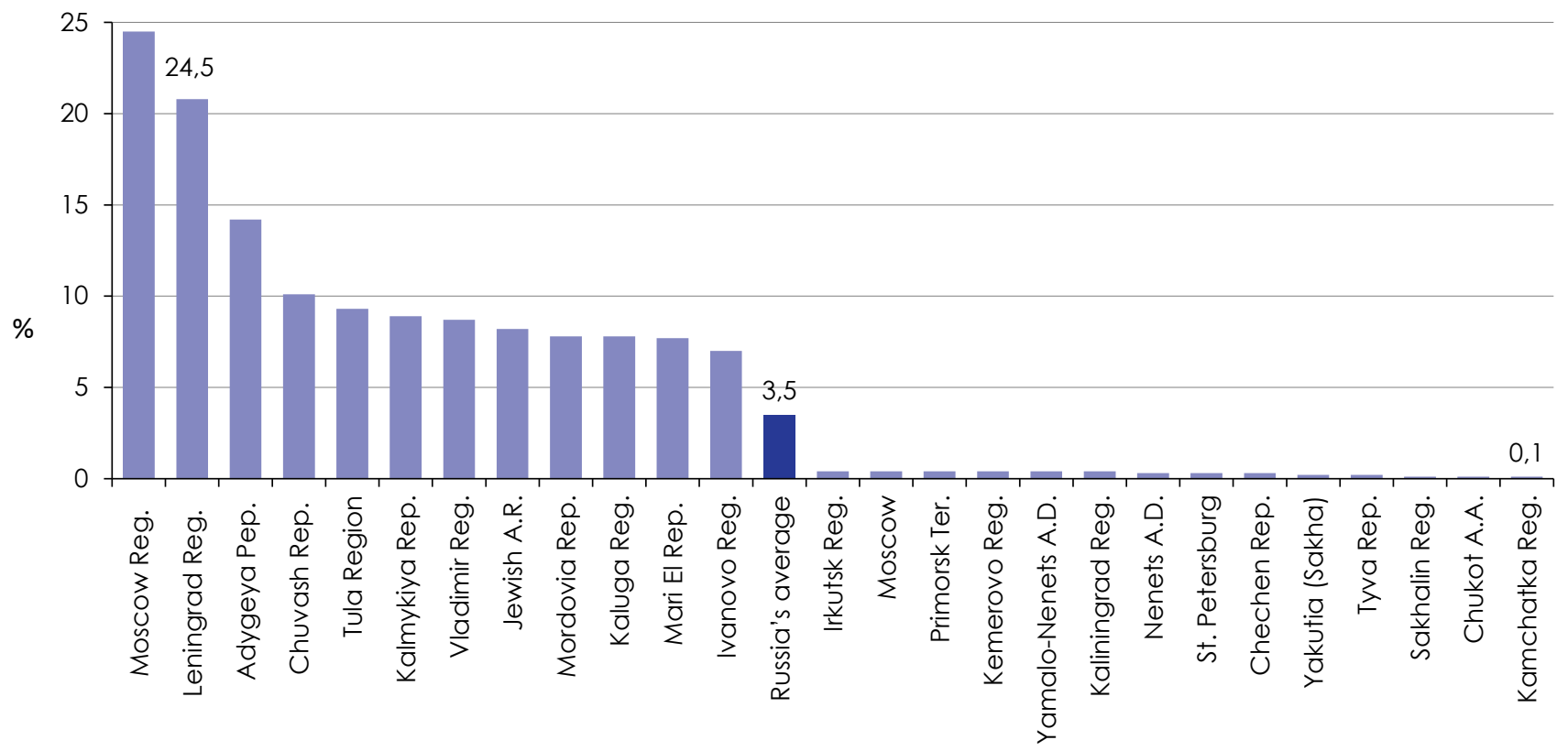

Source: based on the data of the National Population Census 2010.

Fig. 3. A share of persons employed in other constituent entity of Russia in total employed private household population at the age of $15-72$ by region, \%, 2010

port capacity nor significantly attractive places are available. In 14 Russia's regions (other than Siberian regions, Moscow, St. Petersburg, Kaliningrad Region) less than $0.5 \%$ of the working population at the age of 15-72 work in other constituent territories of Russia. This figure exceeds $7 \%$ in almost the same number of regions (Fig. 3). Not counting the first three 'pendulum regions', there would be just less than 10 Russia's regions for whom trans-regional labor mobility is really significant and plays an important role for the labor market in these regions and ... Moscow as recipient of these migrants. 